\title{
Influence of $\mathrm{CH}_{4}$ and $\mathrm{H}_{2} \mathrm{~S}$ availability on symbiont distribution, carbon assimilation and transfer in the dual symbiotic vent mussel Bathymodiolus azoricus
}

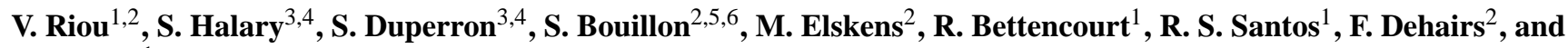 \\ A. Colaço ${ }^{1}$ \\ ${ }^{1}$ Department of Oceanography and Fisheries, IMAR-University of Azores, Horta, Portugal \\ ${ }^{2}$ Department of Analytical and Environmental Chemistry, Vrije Universiteit Brussel, Brussels, Belgium \\ ${ }^{3}$ UPMC Université Paris 06, UMR 7138 SAE AMEX, Paris, France \\ ${ }^{4}$ CNRS UMR 7138 SAE AMEX, Paris, France \\ ${ }^{5}$ Netherlands Institute of Ecology, Centre for Estuarine and Marine Ecology, Yerseke, The Netherlands \\ ${ }^{6}$ Department of Earth and Environmental Sciences, Katholieke Universiteit Leuven, Leuven, Belgium
}

Received: 7 April 2008 - Published in Biogeosciences Discuss.: 29 May 2008

Revised: 27 October 2008 - Accepted: 7 November 2008 - Published: 11 December 2008

\begin{abstract}
High densities of mussels of the genus Bathymodiolus are present at hydrothermal vents of the Mid-Atlantic Ridge. It was previously proposed that the chemistry at vent sites would affect their sulphide- and methane-oxidizing endosymbionts' abundance. In this study, we confirmed the latter assumption using fluorescence in situ hybridization on Bathymodiolus azoricus specimens maintained in a controlled laboratory environment at atmospheric pressure with one, both or none of the chemical substrates. A high level of symbiosis plasticity was observed, methane-oxidizers occupying between 4 and 39\% of total bacterial area and both symbionts developing according to the presence or absence of their substrates. Using $\mathrm{H}^{13} \mathrm{CO}_{3}^{-}$in the presence of sulphide, or ${ }^{13} \mathrm{CH}_{4}$, we monitored carbon assimilation by the endosymbionts and its translocation to symbiont-free mussel tissues. Carbon was incorporated from methane and sulphide-oxidized inorganic carbon at rates 3 to 10 times slower in the host muscle tissue than in the symbiontcontaining gill tissue. Both symbionts thus contribute actively to $B$. azoricus nutrition and adapt to the availability of their substrates. Further experiments with varying substrate concentrations using the same set-up should provide useful tools to study and even model the effects of changes in hydrothermal fluids on B. azoricus' chemosynthetic nutrition.
\end{abstract}

Correspondence to: V. Riou

(virgriou@vub.ac.be)

\section{Introduction}

Mytilids of the genus Bathymodiolus are among the dominant fauna inhabiting sulphide-hydrocarbon cold seeps and hydrothermal vents worldwide (Sibuet and Olu, 1998; Van Dover, 2000). Their nutrition seems to be mainly supported by sulphide- and/or methane-oxidizing bacterial (SOB, MOB) endosymbionts, located in specialized gill epithelial cells (Fisher, 1990). In fact, the coexistence of two distinct bacterial symbionts within a single cell of a multicellular eukaryote was demonstrated for the first time ever in the gills of Bathymodiolus spp. (Cavanaugh et al., 1987; 1992; Fisher et al., 1993). B. puteoserpentis and B. azoricus, the two mussel species present at Mid-Atlantic Ridge (MAR) vent sites, display the same general characteristics, with two distinct morphotypes of Gram-negative endosymbionts in gill bacteriocytes, and the presence of enzymes specific for sulphide and methane oxidizing metabolisms (type I ribulose 1,5-bisphosphate carboxylase/oxygenase RubisCO-, ATP sulfurylase, adenylyl sulfate reductase, and methanol dehydrogenase) (Robinson et al., 1998 and FialaMédioni et al., 2002). Phylogenetic analyses show that the two Mytilid species share the same 16S rRNA phylotype of sulphide-oxidizing $\gamma$-proteobacteria, but harbour two distinct strains (Won et al., 2003). Duperron et al. (2006) found that the MOB 16S rRNA phylotype was also shared between the two mussel species, and that vent chemistry could affect the relative abundance of SOB and MOB. The volume occupied by each type of symbiont present within

Published by Copernicus Publications on behalf of the European Geosciences Union. 
a bacteriocyte, quantified using 3D fluorescence in situ hybridization (FISH) technique, varies from vent site to vent site between B. azoricus specimens (Halary et al., 2008). However, although physiological activity of the symbionts was observed in gills of a hydrothermal vent Bathymodiolid from the Pacific (Fiala-Médioni et al., 1986; Nelson et al. 1995), in the Southern MAR B. puteoserpentis (Robinson et al., 1998) and in live specimens of the seep Bathymodiolid from the Gulf of Mexico (Childress et al., 1986; Fisher and Childress, 1992; Kochevar et al., 1992 and Lee and Childress, 1995), it has to date not been demonstrated in live specimens of B. azoricus.

Stable isotope studies on Bathymodiolids have indicated the presence of two isotopically (and hence, nutritionally) distinct groups of mussels at the MAR (Trask and Van Dover, 1999; Fiala-Médioni et al., 2002 and Colaço et al., 2002a). A first group (bulk tissue $\delta^{13} \mathrm{C} \sim-30 \%$ ) would depend mostly on SOB, while a group with heavier isotopic values of $-20 \%$ o suggests a larger reliance on MOB. B. azoricus is a complex organism which can derive its carbon and nitrogen from two different symbionts, from particulate organic matter and possibly from dissolved organic matter. In such a case, the analysis of stable isotopes at natural abundance in bulk tissue, which provides information about the "average" diet over a certain period of time, is insufficient to accurately delineate the contributions from the different food sources. Incubations with ${ }^{13} \mathrm{C}$-enriched substrates are commonly used to study the activity of pure bacterial cultures as well as the activity of different complex bacterial communities in natural and artificial ecosystems and soils. Autotrophic SOB were already described performing such tracer experiments with ${ }^{13} \mathrm{C}$-labelled bicarbonate (Knief et al., 2003a), as were communities of physiologically active MOB using ${ }^{13} \mathrm{CH}_{4}$ (Knief et al., 2003b). In the present study, we investigated symbiont populations and mussel nutrition in specimens of $B$. azoricus collected from the MAR and kept under various conditions in a controlled laboratory environment (LabHorta facility in the Azores, Colaço and Santos, 2002b). Stable isotope tracer experiments were performed with ${ }^{13} \mathrm{C}$-enriched bicarbonate or methane, followed by analysis of ${ }^{13} \mathrm{C}$ incorporation in mussel tissues. Densities of symbionts were estimated from FISH images using symbiont-specific probes. Results indicate that the symbionts develop in response to the presence or absence of their substrates, and that inorganic carbon and $\mathrm{C}_{1}$ substrates are assimilated and further translocated into symbiont-free mussel tissues.

\section{Material and methods}

\subsection{Study site and sampling}

Acoustically retrievable cages were moored in August 2006 during the MOMARETO cruise (R/V Pourquoi Pas? Ifremer). They were positioned on diffuse venting areas at the
Mid-Atlantic Ridge (MAR) hydrothermal vent field Menez Gwen (MG: $37^{\circ} 51^{\prime} \mathrm{N}, 32^{\circ} 31^{\prime} \mathrm{W}, 817 \mathrm{~m}$ ) where mussel populations are very dense and cover virtually all available rock surfaces. Cages were filled with approximately 400 mussels using the Ifremer ROV VICTOR 6000. Our experiments were performed on adult mussels $(53.6-74.1 \mathrm{~mm}$ shell length, mean $65.5 \pm 3.7 \mathrm{~mm}$ ) from two cages recovered by the Portuguese vessel R/V Arquipélago in January and May 2007. After a 20 min surfacing time, the cage was lifted onboard and mussels were transferred to fresh cooled seawater for a $14 \mathrm{~h}$ transit to Faial Island (Azores). Some wild specimens were dissected on-board. At the Azorean LabHorta facility, mussels were scrubbed clean of visible adhering material, rinsed in chilled seawater and transferred to the hydrothermal vent laboratory set up. They were kept in maintenance conditions (see Sect. 2.2) until the start of tracer experiments (in Sect. 2.3). Maintenance and tracer experiments in LabHorta were monitored daily for $\mathrm{CH}_{4}$ and $\mathrm{H}_{2} \mathrm{~S}$ concentrations, $\mathrm{O}_{2}$ saturation, $\mathrm{pH}$ and temperature.

A first experiment was performed with the mussels collected in January and left to acclimate during 5 days (Table 1), with the aim to describe the effect of sulphide on the incorporation of bicarbonate. Experiments with May mussels were designed to observe (i) B. azoricus' response to prolonged maintenance in the laboratory (Table 2, upper part) and (ii) the evolution of symbiotic populations and carbon incorporation in mussel tissues in response to exposure to only methane, only sulphide or in the absence of stimulation (Table 2, bottom part). Specimens showing the highest ${ }^{13} \mathrm{C}$ incorporation after 4 or 5 days enrichment in the presence of sulphide or methane, respectively, were selected for FISH analyses in Sect. (2.6).

Dissected tissues were frozen and lyophilized, except for the gill parts analysed for FISH. Gill indexes (GI) were calculated from the specimens' gill tissue and rest of body dry weights (total soft tissue dry weight - gill dry weight) according to the following formula:

$\mathrm{GI}=[$ gill tissue dry weight $(\mathrm{g}) /$ rest of body dry weight $(\mathrm{g})] \times 100(1)$

\subsection{Maintenance in LabHorta}

Mussels were placed in $40 \mathrm{~L}$ tanks containing $7.5-10^{\circ} \mathrm{C}$ seawater (warmer water was found to inactivate methane oxidizers in B. childressi; Kochevar et al., 1992). Seawater was oxygenated using compressed air and replaced every second day ( $\mathrm{pH}$ 7.5-9). Methane and sulphide were supplied to support the presence of endosymbionts. A sulphide solution $\left(20 \mathrm{mmol} \mathrm{L}^{-1} \mathrm{Na}_{2} \mathrm{~S}\right.$ in filtered seawater, $\mathrm{pH}$ adjusted with $\mathrm{HCl} 6 \mathrm{~N}$ to 8.6-9.2) was dispensed discontinuously for $15 \mathrm{~min}$ every hour, using a peristaltic pump injecting $2 \mathrm{~mL} \mathrm{~min}^{-1}$. Resulting sulphide concentrations between 1 and $30 \mu \mathrm{mol} \mathrm{L}^{-1}$ were measured using the colorimetric diamine test. Such values are well within the range of the 0 to $62 \mu \mathrm{mol} \mathrm{L}^{-1}$ measured on mussel beds of Northern 
Table 1. January experimental design, with median $\mathrm{CH}_{4}$ and $\mathrm{H}_{2} \mathrm{~S}$ concentrations $(\mu \mathrm{M})$ in the presence or absence of $10 \% \mathrm{H}^{13} \mathrm{CO}_{3}^{-}$, and $\mathrm{O}_{2}$ saturation ( $\pm \mathrm{SD}$ ) experienced by the sampled mussels over the duration of the acclimation and of the labelling experiment (days). " $n$ " represents the number of specimens analysed for their gill index (GI), bulk tissue and/or phospholipid fatty acids (PLFA) carbon isotopic signature $\left(\delta^{13} \mathrm{C}\right)$.

\begin{tabular}{|c|c|c|c|c|c|c|c|c|c|c|}
\hline & 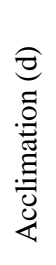 & 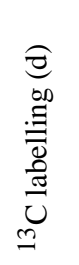 & $\mathrm{CH}_{4}$ & $\mathrm{H}_{2} \mathrm{~S}$ & $\mathrm{O}_{2}(\%)$ & $\mathrm{H}^{13} \mathrm{CO}_{3}^{-}$ & $n$ & GI & $\begin{array}{l}\delta^{13} \mathrm{C} \\
\text { Gill, } \\
\text { Mantle, } \\
\text { Muscle, } \\
\text { Rest }\end{array}$ & $\begin{array}{l}\delta^{13} \mathrm{C} \text { Gill } \\
\text { PLFA }\end{array}$ \\
\hline Wild & - & - & - & - & - & - & 10 & + & + & - \\
\hline Acclimated & 5 & - & $11 \pm 50$ & $5 \pm 23$ & $57 \pm 27$ & - & 3 & + & - & - \\
\hline${ }^{13} \mathrm{C}+\mathrm{H}_{2} \mathrm{~S}$ & 5 & 15 & - & $4 \pm 4$ & $84 \pm 10$ & + & 3 & - & + & + \\
\hline${ }^{13} \mathrm{C} \mathrm{no}_{2} \mathrm{~S}$ & 5 & 15 & - & - & $87 \pm 13$ & + & 3 & - & + & + \\
\hline $\mathrm{H}_{2} \mathrm{~S}$ no ${ }^{13} \mathrm{C}$ & 5 & 15 & - & $6 \pm 3$ & $88 \pm 10$ & - & 3 & - & - & + \\
\hline
\end{tabular}

Table 2. May experimental design, with median ${ }^{(13)} \mathrm{CH}_{4}$ and $\mathrm{H}_{2} \mathrm{~S}$ concentrations $(\mu \mathrm{M})$ in the presence or absence of $16.3 \% \mathrm{H}^{13} \mathrm{CO}_{3}^{-}$, and $\mathrm{O}_{2}$ saturation ( $\pm \mathrm{SD}$ ) experienced by the sampled mussels over the duration of the experiment (days). " $n$ " represents the number of specimens analysed for their gill index (GI), bulk tissue carbon isotopic signature $\left(\delta^{13} \mathrm{C}\right)$ and/or observed by fluorescence in situ hybridisation (FISH).

\begin{tabular}{|c|c|c|c|c|c|c|c|c|c|}
\hline Days & $\mathrm{CH}_{4}$ & $\mathrm{H}_{2} \mathrm{~S}$ & ${ }^{13} \mathrm{CH}_{4}$ & $\mathrm{H}^{13} \mathrm{CO}_{3}^{-}$ & $\mathrm{O}_{2}(\%)$ & $n$ & GI & $\begin{array}{c}\delta^{13} \mathrm{C} \\
\text { Gill, Muscle }\end{array}$ & $\begin{array}{c}\text { FISH } \\
(n)\end{array}$ \\
\hline \multicolumn{10}{|c|}{ Maintenance } \\
\hline 0 & & & - & - & & 10 & + & + & 1 \\
\hline 22 & $25 \pm 20$ & $11 \pm 7$ & - & - & $35 \pm 8$ & 3 & + & - & - \\
\hline 32 & $28 \pm 17$ & $12 \pm 7$ & - & - & $41 \pm 15$ & 3 & + & - & - \\
\hline 38 & $28 \pm 16$ & $13 \pm 7$ & - & - & $43 \pm 14$ & 1 & - & - & 1 \\
\hline 42 & $28 \pm 16$ & $12 \pm 8$ & - & - & $43 \pm 13$ & 2 & + & - & - \\
\hline 52 & $28 \pm 15$ & $10 \pm 8$ & - & - & $42 \pm 12$ & 3 & + & - & - \\
\hline \multicolumn{10}{|c|}{ Tracer experiments after 38 days maintenance } \\
\hline \multirow{3}{*}{1} & - & - & - & - & 39 & 1 & + & + & - \\
\hline & - & 9 & - & + & 41 & 1 & + & + & - \\
\hline & - & - & 28 & - & 47 & 1 & + & + & - \\
\hline \multirow{2}{*}{4} & - & - & - & - & $44 \pm 7$ & 3 & + & + & 1 \\
\hline & - & $8 \pm 2$ & - & + & $45 \pm 6$ & 3 & + & + & 1 \\
\hline 5 & - & - & $33 \pm 98$ & - & $33 \pm 13$ & 3 & + & + & 1 \\
\hline 15 & - & - & $28 \pm 51$ & - & $33 \pm 13$ & 10 & + & + & - \\
\hline \multirow{2}{*}{20} & - & - & - & - & $42 \pm 12$ & 10 & + & + & - \\
\hline & - & $6 \pm 8$ & - & + & $44 \pm 11$ & 10 & + & + & - \\
\hline
\end{tabular}




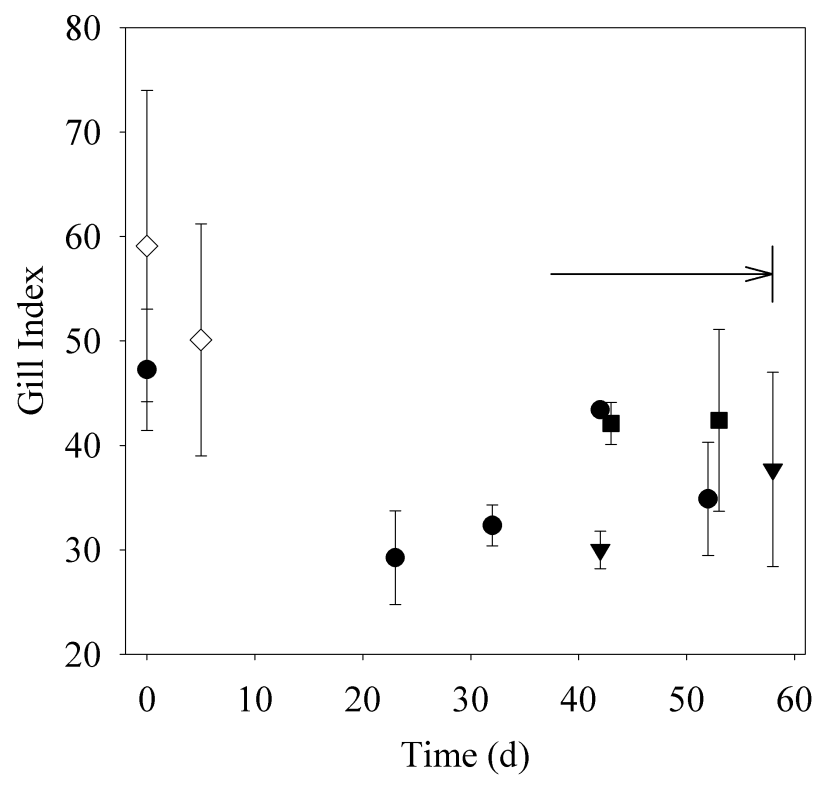

Fig. 1. Variations in gill index with time spent in aquarium in the presence of $\mathrm{CH}_{4}$ and/or $\mathrm{H}_{2} \mathrm{~S}$ (mean $\pm \mathrm{SD}$ ). Open diamonds: January wild $(n=10)$ and aquarium $(n=3)$ mussels. Filled symbols stand for May specimens and an arrow indicates the start and end of tracer experiments. Circles: wild $(n=10)$ and aquarium mussels maintained with $\mathrm{H}_{2} \mathrm{~S}+\mathrm{CH}_{4}$ (22 days: $n=3,32$ days: $n=3,42$ days: $n=2,52$ days: $n=3$ ). Triangles: $\mathrm{NaH}^{13} \mathrm{CO}_{3}+\mathrm{H}_{2} \mathrm{~S}$ tracer mussels (enrichment day 4: $n=3$, day 20: $n=10$ ). Squares: ${ }^{13} \mathrm{CH}_{4}$ tracer mussels (enrichment day 5: $n=3$, day 15: $n=10$ ).

MAR vent sites (Sarradin et al., 1998). Methane was bubbled continuously in seawater and dissolved methane concentration was monitored by sampling $60 \mathrm{~mL}$ seawater in a $300 \mathrm{~mL}$ bottle which was rolled for $20 \mathrm{~min}$ before measuring the headspace $\mathrm{CH}_{4}$ concentration with a Gasurveyor 524. Since high methane concentrations above $300 \mu \mathrm{mol} \mathrm{L}^{-1}$ were found inhibitory for symbionts of $B$. childressi exhibiting high methane consumption rates (Kochevar et al., 1992), we tried to maintain $\mathrm{CH}_{4}$ concentration below this level (8$\left.92 \mu \mathrm{mol} \mathrm{L}^{-1}\right)$. The effect of the imposed laboratory conditions on the mussels was assessed by statistical MannWhitney U test and Kruskal-Wallis non-parametric analyses.

\subsection{Stable isotope tracer experiments}

All stable isotope enriched chemicals were purchased from Campro Scientific (The Netherlands). January tracer experiments (Table 1) were performed for 15 days in artificial seawater $\left(425 \mathrm{mmol} \mathrm{L}^{-1} \mathrm{NaCl}, 9 \mathrm{mmol} \mathrm{L}^{-1} \mathrm{KCl}\right.$, $9.3 \mathrm{mmol} \mathrm{L}^{-1} \mathrm{CaCl}_{2}, 25.5 \mathrm{mmol} \mathrm{L}^{-1} \mathrm{MgSO}_{4}, 23 \mathrm{mmol} \mathrm{L}^{-1}$ $\mathrm{MgCl}_{2}, 2 \mathrm{mmol} \mathrm{L}^{-1}$ total $\mathrm{NaHCO}_{3}$; adjusted to $\mathrm{pH}$ 8) filtered on a $0.2 \mu \mathrm{m}$ membrane and replaced every second day $(\mathrm{pH}$ $8.0-8.5 ; 9.3-10.7^{\circ} \mathrm{C}$ ). Enrichment was obtained by replacing $10 \%$ of natural abundance sodium bicarbonate by $\mathrm{NaH}^{13} \mathrm{CO}_{3}$ $\left(99 \%{ }^{13} \mathrm{C}\right)$. Monitored sulphide concentrations were in the range of $2-14 \mu \mathrm{mol} \mathrm{L}^{-1}$. May experiments (Table 2) were performed in $0.2 \mu \mathrm{m}$-filtered natural seawater replaced every second day $\left(\mathrm{pH} 7.5-8.5 ; 7.9-9.8^{\circ} \mathrm{C}\right)$ supplemented (or not) with methane $\left(14-200 \mu \mathrm{mol} \mathrm{L}^{-1} 25 \%{ }^{13} \mathrm{C}\right)$ or hydrogen sulphide with bicarbonate $\left(\mathrm{H}_{2} \mathrm{~S} 0-32 \mu \mathrm{mol} \mathrm{L}^{-1}\right.$ supplemented with $\mathrm{NaH}^{13} \mathrm{CO}_{3} 99 \%$ to obtain a concentration of $2.85 \mathrm{mmol} \mathrm{L}^{-1} 16.3 \%{ }^{13} \mathrm{C}$ ), for 15 and 20 days, respectively. At each sampling, mussels were opened and rinsed in distilled water to discard unincorporated tracers.

\subsection{Fatty acids extraction}

Lyophilized gill tissues were ground to a fine powder using a mortar and pestle. All glassware was decontaminated for $4 \mathrm{~h}$ at $450^{\circ} \mathrm{C}$ prior to use. Lipids were extracted using a modified version of the Bligh and Dyer method (White et al., 1979) using chloroform/methanol/phosphate buffer $\mathrm{pH} 7.4$ in 1:1:0.9 final volume proportions to form a biphasic system. Total lipids retrieved in the chloroform phase were applied onto activated silicic acid columns and partitioned into apolar, neutral and polar lipids by sequential elution with chloroform, acetone, and methanol, respectively. Lipid fractions were dried under nitrogen flux and immediately resuspended in $2 \mathrm{~mL}$ of a fresh solution of methanol/hydrochloric acid $37 \% /$ chloroform (10:1:1 volume) to form fatty acid methyl esters (FAMEs) by trans-methylation reaction $(60 \mathrm{~min}$ at $\left.90^{\circ} \mathrm{C}\right)$.

\subsection{Stable isotope analyses}

FAME extracts were transferred to tin capsules for liquids (previously decontaminated with acetone) and chloroform was evaporated under mild conditions $\left(37^{\circ} \mathrm{C}\right.$, to avoid the loss of the most volatile FAMEs).

Aliquots of lyophilized tissue powder were weighed into silver cups (previously decontaminated for $4 \mathrm{~h}$ at $450^{\circ} \mathrm{C}$ ) and acidified with a few drops of dilute $\mathrm{HCl}(5 \%)$ before analysis, to remove any possible trace of carbonates. Tissues were redried overnight at $60^{\circ} \mathrm{C}$.

$\delta^{13} \mathrm{C}$ analyses were performed on a Flash1112 elemental analyzer, coupled to a Delta V via a Conflo III interface (Thermo Finnigan). All carbon stable isotope ratios are expressed relative to the conventional reference (VPDB limestone) as $\delta$ values, defined as:

$\delta^{13} \mathrm{C}=\left[\left(\mathrm{R}_{\text {sample }}-\mathrm{R}_{\text {standard }}\right) / \mathrm{R}_{\text {standard }}\right] \times 10^{3}[\%]$ where $\mathrm{R}={ }^{13} \mathrm{C} /{ }^{12} \mathrm{C}$

Or as Atom percent values, defined as:

$\mathrm{A}=\left[{ }^{13} \mathrm{C} /\left({ }^{13} \mathrm{C}+{ }^{12} \mathrm{C}\right)\right] \times 100[\%]$

The reference material used as standard for carbon isotopic ratio measurement was sucrose (IAEA-CH-6). The standard followed the same analytical processes as the unknown samples. 
Net carbon incorporation in the mussel tissues $\left(\mathrm{C}_{\mathrm{inc}}\right.$, in

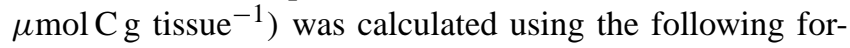
mula:

$\mathrm{C}_{\mathrm{inc}}=\left[\left(\mathrm{A}_{\mathrm{exp}}-\mathrm{A}_{\text {control }}\right) \times \mathrm{C}_{\text {tissue }}\right] /\left(\mathrm{A}_{\text {substrate }}-\mathrm{A}_{\text {control }}\right)(4)$

Where $\mathrm{A}_{\text {exp }}$ is the ${ }^{13} \mathrm{C}$ atom percent measured in the mussel after the tracer experiment, $\mathrm{A}_{\text {control }}$ is the ${ }^{13} \mathrm{C}$ atom percent measured in the control mussel, $\mathrm{C}_{\text {tissue }}$ is the carbon content of the tissue analyzed $\left(\mu \mathrm{mol} \mathrm{Cg}\right.$ tissue $\left.^{-1}\right)$ and $\mathrm{A}_{\text {substrate }}$ the ${ }^{13} \mathrm{C}$ atom percent of the substrate used in the experiment (i.e., $25 \%$ for $\mathrm{CH}_{4}$, as given by the supplier, or $16.3 \%$ for $\mathrm{NaHCO}_{3}$ and $22.2 \%$ for $\mathrm{CH}_{3} \mathrm{OH}$, as calculated from the preparation).

\subsection{Fluorescence In Situ Hybridization (FISH)}

FISH was performed according to the protocol developed by Halary et al. (2008) with a few modifications. Upon recovery of selected mussel specimens, the most anterior part of their left gill was fixed in $2 \%$ formaldehyde $\left(2-4 \mathrm{~h}, 4^{\circ} \mathrm{C}\right)$, rinsed twice with filtered seawater, and stored at $-20^{\circ} \mathrm{C}$ in $1: 1$ ethanol/filtered seawater. In the lab, gill tissue was embedded in polyester wax and $10 \mu \mathrm{m}$-thick sections were cut using a microtome (JUNG, Heidelberg, Germany), collected on Superfrost ${ }^{\circledR}$ Plus slides (Roth, Germany), and hybridized as previously described (Halary et al., 2008) using the ATTO488labelled ImedM probe (5'-ACCAGGTTGTCCCCCACTAA3', Duperron et al., 2008) specific for the methane-oxidizing symbiont and the Cy5-labelled BangT-642 probe (5'CCTATACTCTAGCTTGCCAG-3', Duperron et al., 2005) specific for the sulphide-oxidizing symbiont. Images were acquired using a BX61 microscope (Olympus Optical Co., Tokyo, Japan) under a $10 \times$ objective (NA 1.30). The green channel corresponding to the ImedM probe (methaneoxidizers) and the blue channel corresponding to the BangT probe (sulphide-oxidizers) were binarized by applying a luminosity threshold to distinguish between background fluorescence and probe signal, and numbers of pixels belonging to each type of symbiont were computed using the ImageJ software (Abramoff, 2001). Total area occupied by bacteria and respective proportions of each phylotype were computed for the whole image (one image per specimen, around 20 gill filaments per image). For an inter-comparison between images, bacterial areas were normalized by dividing areas by the total length of filaments visible and measured on each picture.

\section{Results}

3.1 Effect of the maintenance in aquarium on mussel condition

Mussels collected in January were allowed to recover from the decompression stress during 5 days at atmospheric pressure (transport followed by LabHorta) with $\mathrm{CH}_{4}$ and $\mathrm{H}_{2} \mathrm{~S}$ to ensure the survival of endosymbionts ("Acclimated", Table 1). A quick drop of their gill index (GI) could be noticed over this short period (although not statistically significant, Mann-Whitney U test $p=0.237$, Fig. 1). This drop was also observed for May mussels kept in the presence of $\mathrm{H}_{2} \mathrm{~S}$ and $\mathrm{CH}_{4}$ (see concentrations in Table 2) up to 38 days before starting the tracer experiments (aquarium mean $\mathrm{GI}=33.7, n=7$; wild animals mean GI $=47.3, n=10$, KruskalWallis $p=0.006$, Fig. 1). Subsequent to this rapid loss in gill weight, no further significant changes in GI were observed between individuals collected at different moments during the maintenance period (from day 23 to 52, Kruskal-Wallis $p=0.115$ ). When compared to mussels kept in maintenance conditions, the GIs of specimens from the tracer experiments did not decrease significantly and rather increased slightly in the ${ }^{13} \mathrm{CH}_{4}$ experiment (Fig. 1, Kruskal-Wallis, $n=22: \mathrm{CH}_{4}$ $p=0.041, \mathrm{H}_{2} \mathrm{~S} p=0.598$, control $p=0.262$ ).

3.2 Endosymbiont populations' response to experimental treatments

Gill filaments from May mussels were observed using FISH to assess the effects of the maintenance period in LabHorta and of the tracer experiments on symbiont populations (Fig. 2). Estimates of symbiont areas and proportions for a wild specimen, for a specimen collected at the start of the experiments (after the maintenance period) and others after 4 to 5 days in the absence or presence of either $\mathrm{CH}_{4}$ or $\mathrm{H}_{2} \mathrm{~S}$ are displayed in Table 3. Gill filaments of aquarium specimens appeared narrower than the ones from a wild mussel dissected immediately after the cage recovery and carried much less bacteria (Fig. 2A-B). The sections observed showed a decrease in area covered by bacteria by a factor of 4 (from 16.7 to $3.7 \mu \mathrm{m}^{2} / \mu \mathrm{m}$ filament), and indicated a shift in symbiont relative areas, with methane-oxidizing bacteria (MOB) representing $14 \%$ of the total area occupied by bacteria in acclimated specimens, versus $24 \%$ in fresh specimens (Table 3). At the beginning of the tracer experiments, bacterial densities appear low. A mussel kept four days in filtered seawater devoid of $\mathrm{CH}_{4}$ and $\mathrm{H}_{2} \mathrm{~S}$ also displayed a lower total area occupied by bacteria of $2.1 \mu \mathrm{m}^{2} / \mu \mathrm{m}$ filaments. The exclusive presence of $86.9 \pm 98.0 \mu \mathrm{mol} \mathrm{L}^{-1} \mathrm{CH}_{4}$ seemed to favour MOB which represented $39 \%$ of total bacterial area (Fig. 2C). Four days enrichment with exclusively $7.7 \pm 1.6 \mu \mathrm{mol} \mathrm{L}{ }^{-1} \mathrm{H}_{2} \mathrm{~S}$ resulted in higher overall bacterial areas with a high proportion of SOB representing $96 \%$ of total bacterial area (Fig. 2D).

\subsection{Sulphide induced $\mathrm{CO}_{2}$ incorporation}

A low incorporation of ${ }^{13} \mathrm{C}$ from $\mathrm{HCO}_{3}^{-}$was observed in the absence of $\mathrm{H}_{2} \mathrm{~S}$, which increased considerably when B. azoricus was supplied with $\mathrm{H}_{2} \mathrm{~S}$ (Fig. 3). Highest incorporation was found in the gill tissue, followed by other tissues such as the digestive tract and vital organs which displayed 
Table 3. Results from FISH image processing. The $\mathrm{CH}_{4} / \mathrm{H}_{2} \mathrm{~S}$ ratio of 1.2 reported for fresh mussels, is a mean from end-member fluids at Menez Gwen (0.67-1.75, Desbruyères et al., 2000), which might not be representative of the situation in their immediate environment.

\begin{tabular}{cccccc}
\hline & $\begin{array}{c}\mathrm{CH}_{4} / \\
\mathrm{H}_{2} \mathrm{~S}\end{array}$ & $\begin{array}{c}\text { Surf Symb } \mu \mathrm{m}^{2} / \\
\text { Fil length } \mu \mathrm{m}\end{array}$ & $\begin{array}{c}\% \\
\text { MOB }\end{array}$ & $\begin{array}{c}\% \\
\text { SOB }\end{array}$ & $\begin{array}{c}\text { MOB } \\
\text { /SOB }\end{array}$ \\
\hline Fresh & 1.2 & 16.7 & 24 & 76 & 0.32 \\
38 days $\mathrm{H}_{2} \mathrm{~S}+\mathrm{CH}_{4}$ & 2.2 & 3.7 & 14 & 86 & 0.17 \\
+4 days Nothing & $(-)$ & 2.1 & 29 & 71 & 0.41 \\
+4 days $\mathrm{H}_{2} \mathrm{~S}$ & $100 \% \mathrm{H}_{2} \mathrm{~S}$ & 5.1 & 4 & 96 & 0.04 \\
+5 days $\mathrm{CH}_{4}$ & $100 \% \mathrm{CH}_{4}$ & 3.1 & 39 & 61 & 0.64 \\
\hline
\end{tabular}
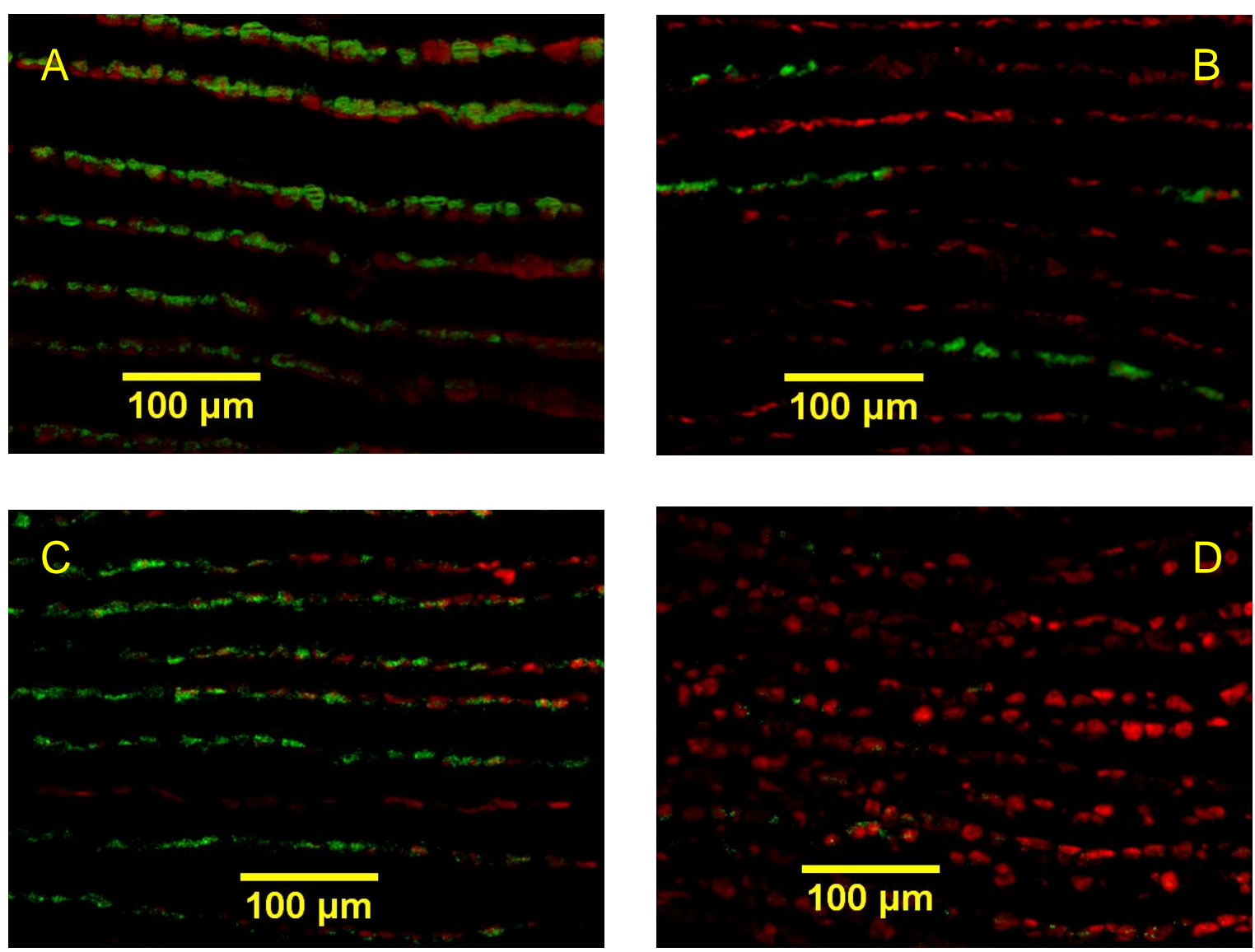

Fig. 2. FISH observations of transverse sections of gill filaments, displaying methane- (green) and sulphide-oxidisers (red) in May mussels. A-B: gills from a fresh specimen (A) and a specimen maintained 38 days (B) in LabHorta with $\mathrm{H}_{2} \mathrm{~S}+\mathrm{CH}_{4}$. C-D: specimens observed after 5 days with ${ }^{13} \mathrm{CH}_{4}\left(\right.$ C) or 4 days with $\mathrm{H}_{2} \mathrm{~S}+\mathrm{NaH}^{13} \mathrm{CO}_{3}$ (D).

much lower incorporations. The analyses of gill tissue phospholipid fatty acid methyl esters (PLFA) also showed a coupling between enriched inorganic carbon incorporation and the presence of $\mathrm{H}_{2} \mathrm{~S}$ (Fig. 4). $\quad \delta^{13} \mathrm{C}$ analysis of fatty acid methyl esters (FAMEs) from gill lipid fractions of mussel A (the mussel specimen displaying the highest $\delta^{13} \mathrm{C}$ values after January experiments) showed the highest enrichment in the polar PLFA, followed by the FAMEs from the neutral fraction. A significantly lower $\delta^{13} \mathrm{C}$ was found in fatty acids associated with the apolar lipid fraction among which can be found di- and tri-acylglycerols and cholesterol derivatives. 


\section{$3.4 \mathrm{CO}_{2}$ and $\mathrm{CH}_{4}$ incorporation rates}

After 4 and 5 days of exposure to ${ }^{13} \mathrm{C}$-labelled $\mathrm{HCO}_{3}^{-}$(in the presence of $\mathrm{H}_{2} \mathrm{~S}$ ) or $\mathrm{CH}_{4}$, B. azoricus gill tissue already showed ${ }^{13} \mathrm{C}$ abundances significantly higher than background levels (Kruskal-Wallis $p=0.049$ for both treatments). At each sampling time, $\delta^{13} \mathrm{C}$ values tended to be higher in gill than in muscle tissue. Labelling of the gill tissue appeared uniform between the different mussel specimens after 4 days in $\mathrm{H}_{2} \mathrm{~S}$. However, strong differences in $\delta^{13} \mathrm{C}$ between individuals were observed after 15 days with enriched $\mathrm{CH}_{4}$ and 20 days with $\mathrm{H}_{2} \mathrm{~S}$ and $\mathrm{H}^{13} \mathrm{CO}_{3}^{-}$(Fig. 5, left panel). In the gill tissue, carbon incorporation rates varied from 151 to $323 \mathrm{nmol} \mathrm{Cg}$ dry tissue ${ }^{-1} \mathrm{~h}^{-1}$ after 20 days in the $\mathrm{H}_{2} \mathrm{~S}+\mathrm{H}^{13} \mathrm{CO}_{3}^{-}$experiment (sulphide concentration: 0$32 \mu \mathrm{mol} \mathrm{L}{ }^{-1}$ ), and from 56 to $228 \mathrm{nmol} \mathrm{Cg}$ dry tissue ${ }^{-1} \mathrm{~h}^{-1}$ with ${ }^{13} \mathrm{CH}_{4}\left(14-200 \mu \mathrm{mol} \mathrm{L}{ }^{-1}\right)$. Muscle tissues net incorporation rates ranged from 52 to $104 \mathrm{nmol} \mathrm{Cg}$ dry tissue ${ }^{-1} \mathrm{~h}^{-1}$ in the $\mathrm{H}_{2} \mathrm{~S}+\mathrm{H}^{13} \mathrm{CO}_{3}^{-}$experiment, and from 11 to $21 \mathrm{nmol} \mathrm{Cg}$ dry tissue ${ }^{-1} \mathrm{~h}^{-1}$ in the ${ }^{13} \mathrm{CH}_{4}$ experiment (Fig. 5, right panel).

\section{Discussion}

Because of its capacity to recover and survive in aquaria for several months after the post-retrieval decompression stress, increasing data is being obtained from live Bathymodiolus azoricus maintained in aquaria at atmospheric pressure in the presence or absence of $\mathrm{CH}_{4}$ and $\mathrm{H}_{2} \mathrm{~S}$ for the endosymbionts. Immune responses (Bettencourt et al., 2007), biochemical responses to recovery stress (Dixon et al., 2004) and to metal exposure (Company et al., 2008) have been investigated using such settings. Dixon et al. (2004) saw higher levels of DNA damage in mussels kept in the presence of methane and sulphide than in some kept without any "food supplement". In a recent study, Bettencourt et al. (2008) investigated the physiological state of mussels during acclimatization to atmospheric pressure in the absence of dissolved gases over the course of several months post-capture and concluded that our laboratory set up was a suitable system to study physiological reactions. Response of symbionts to the experimental conditions was barely examined. A preliminary study on sulphide-oxidizing bacterial symbionts (SOB) showed, on transmission electron micrographs, the loss and potential reacquisition of SOB (Kadar et al., 2005).

In the present study we tried to gain insight on the symbiont distributions, physiology and impact on the nutrition of B. azoricus. Gill indexes and fluorescence in situ hybridisation observations of gill filaments indicate that despite a strong post-collection initial stress, with a marked decrease in total symbiont abundances and gill dry weight, both bacterial populations can be maintained in the gill tissue of mussels kept in aquaria. Furthermore, incubation experiments suggest that the presence of either sulphide or methane

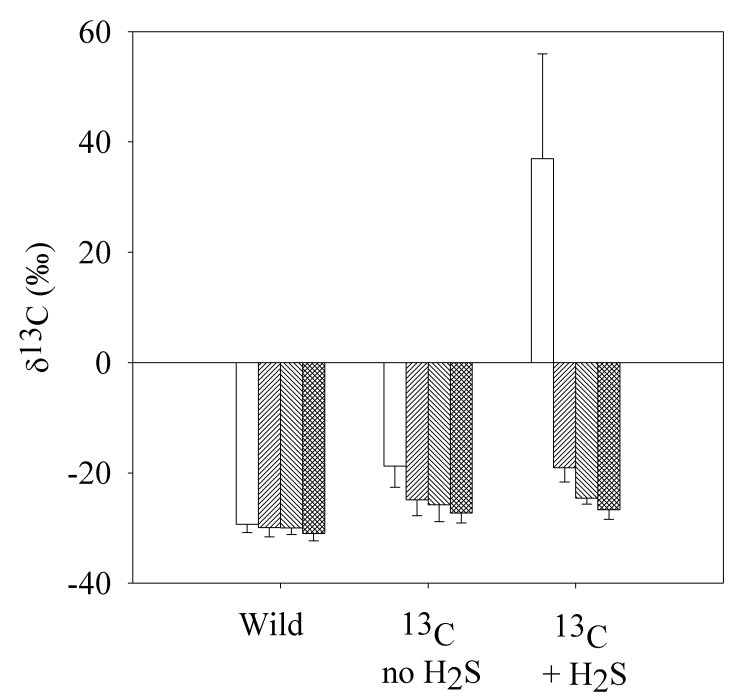

Fig. 3. January mussels' tissues $\delta^{13} \mathrm{C}$ values (bars from left to right: gill, rest, muscle and mantle). Wild $(n=10$, mean \pm SD) or after 5 days acclimatization at atmospheric pressure followed by 15 days in the presence of $10 \%{ }^{13} \mathrm{C}$ enriched bicarbonate with $\left({ }^{13} \mathrm{C}+\mathrm{H}_{2} \mathrm{~S}, n=3\right.$, mean $\left.\pm \mathrm{SD}\right)$ or without sulphide $\left({ }^{13} \mathrm{C}\right.$ no $\mathrm{H}_{2} \mathrm{~S}$, $n=3$, mean $\pm \mathrm{SD})$.

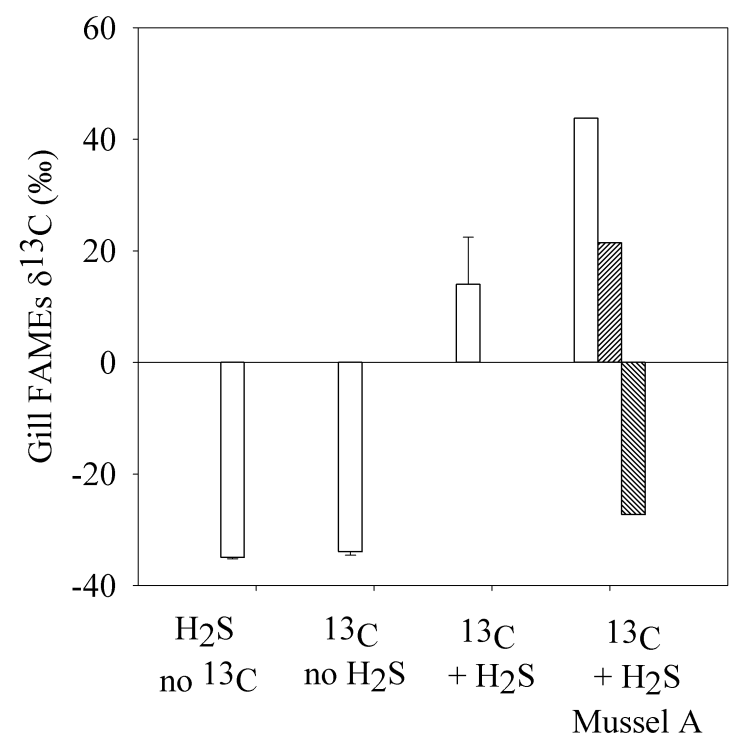

Fig. 4. $\delta^{13} \mathrm{C}$ values of FAMEs (uncorrected for the additional carbon from the methylation) from polar lipids extracted from January tracer mussels' gills (white bars, $n=3$, mean $\pm \mathrm{SD}$ ). For mussel A from the ${ }^{13} \mathrm{C}+\mathrm{H}_{2} \mathrm{~S}$ incubation, polar, neutral and apolar fatty acids were measured (bars from left to right, respectively).

alone favours the increase in absolute and relative abundance of SOB and methane-oxidizing bacterial symbionts (MOB), respectively (Table 3). This supports the hypothesis that symbiont populations react to changes in environmental parameters, in particular to the balance between sulphide and 

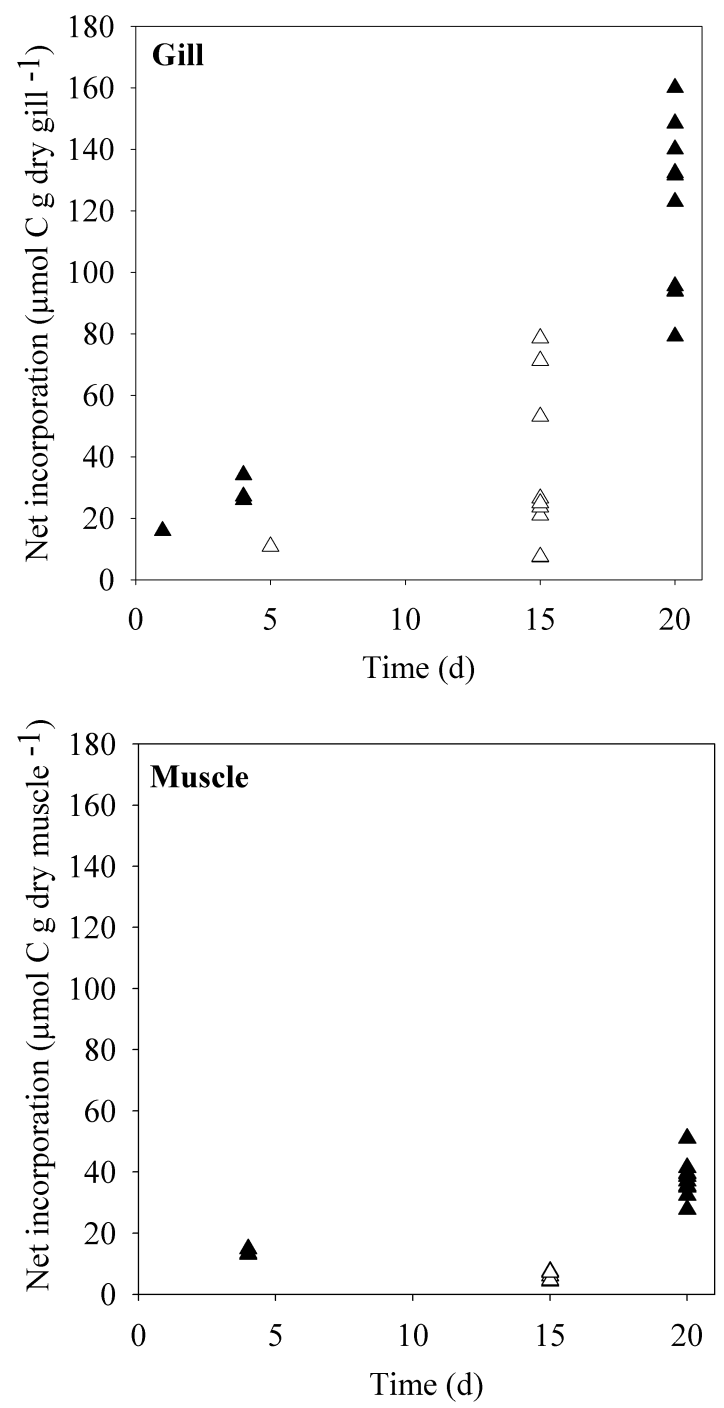

Fig. 5. Carbon net incorporation through time in gill (left panel) and muscle (right panel) tissues from each specimen of May tracer experiments (filled triangles: $\mathrm{NaH}^{13} \mathrm{CO}_{3}+\mathrm{H}_{2} \mathrm{~S}$, empty triangles: ${ }^{13} \mathrm{CH}_{4}$ ).

methane, and thus optimize the use of available compounds as suggested by previous authors (Trask and Van Dover, 1999; Colaço et al., 2002a; Salerno et al., 2005; Duperron et al., 2007). The range of variation observed in symbiont relative abundances, with MOB occupying between 4 and 39\% of total bacterial area in specimens of this study (Table 3), confirms the high level of plasticity of the dual symbiosis. Although our data must be interpreted with caution as only one individual per experimental condition was analyzed, the fact that observations qualitatively agree with expected results is a strong indication that our set-up is appropriate for the enrichment of each endosymbiont. Recently, a 3D-FISH technique was employed to quantify the effect of a sulphide pulse in a similar experimental set-up, on the volume and relative abundance of symbionts in mussel gills (Halary et al.,
2008). We herein provide a first indication that MOB also respond to a methane pulse.

Stable isotope tracer experiments demonstrate that $\mathrm{H}_{2} \mathrm{~S}$ stimulates the assimilation of inorganic carbon, most probably by SOB endosymbionts. Indeed, SOB carry out chemolithoautotrophic organic production via the CalvinBenson cycle, whereby energy for $\mathrm{CO}_{2}$ fixation by the enzyme RuBisCO derives from sulphide oxidation (Fisher, 1990). Our experiments show that most of the incorporated tracer is found in the gill tissue that hosts high densities of bacteria, as opposed with mantle, muscle or other tissues (Fig. 3). The analysis of ${ }^{13} \mathrm{C}$ enrichment in fatty acids from the different fractions of gill extracted lipids (Fig. 4) reveals that for mussels exposed to $\mathrm{H}_{2} \mathrm{~S}$, the polar fraction (consisting in phosphoglycerolipids) is the most ${ }^{13} \mathrm{C}$-enriched fraction in terms of fatty acids, while the apolar fraction shows almost no enrichment. Apolar lipids consist mainly in acylglycerols, free fatty acids, hydrocarbons, pigments, sterols and waxes. Bacteria do not generally synthesise sterols de novo (except for some methylotrophs, Pearson et al., 2003) and do not store acylglycerols as in plant or animal cells. The fact that inorganic carbon is first incorporated in the main components of Gram-negative bacterial membranes (phospholipids, Kates, 1964) and not in apolar lipids originating from the host tissues is an additional indication that $\mathrm{CO}_{2}$ was fixed by SOB. However, we also see a low level of ${ }^{13} \mathrm{C}$ assimilation in mussel tissues in the absence of $\mathrm{H}_{2} \mathrm{~S}$ (Fig. 3), which was also observed in an earlier study using radio-active bicarbonate with $B$. thermophilus gill homogenates (Belkin et al., 1986). Various mechanisms can be invoked to explain this inorganic carbon fixation in the absence of $\mathrm{H}_{2} \mathrm{~S}$ :

i) Mussels encountered severe hypoxia (more than $6 \mathrm{~h}$ ), during prolonged closing of their valves probably in reaction to physical stress (light or vibrations in the LabHorta container, for example). In such conditions, stored glycogen (which can reach $10 \%$ of the dry mass in B. thermophilus, Smith, 1985) becomes the major energy source for the mussel, and the Embden-Merehof-Parnas glycogenolysis pathway deviates from its normal aerobic route, to carboxylate phosphoenolpyruvate (PEP), producing oxaloacetate (Grieshaber et al., 1994). PEP carboxykinase could thus incorporate ${ }^{13} \mathrm{C}$-enriched inorganic carbon entrapped in the valve cavity into oxaloacteate and subsequent end-products such as succinate (as seen in Mytilus edulis, de Zwaan et al., 1983) or other organic acids. However, the effect of any enhanced glycogenolysis would probably result in all tissues displaying the same level of label incorporation, whereas we observe ${ }^{13} \mathrm{C}$ incorporation mainly in gill tissue, and only to a lesser extent in other tissues. Other mechanisms must therefore be involved;

ii) $\mathrm{CO}_{2}$ is fixed by one or both symbiont types via anaplerotic reactions using PEP Carboxylase identified in numerous chemolithoautotrophic and even in methylotrophic bacteria (Glover, 1983; Schobert and Bowien, 1984; MüllerKraft et al., 1991); 
iii) Sulphur or thiosulfate reserves are present in the gill tissue and anaerobic sulphide production occurs after prolonged valve closing (see Arndt et al., 2001 and Pruski et al., 2002, who reports that a large fraction of the sulphur in gills of $B$. azoricus specimens is present in the zero oxidation state);

iv) MOB harbour a RubisCO activity as observed in type X-methane oxidizers (Baxter et al., 2002) and in Bathymodiolus sp. (Elsaied et al., 2006) and would also incorporate inorganic carbon by chemoorganoautotrophy (using formate as a growth substrate, Baxter et al., 2002). More experiments and biochemical analyses would be needed to understand the processes involved in inorganic carbon fixation in the absence of stimulation with sulphide, and at this stage we cannot eliminate any of the abovementioned hypotheses.

Distribution of labelled carbon in the different mussel tissues suggests that in the case of carbon uptake by SOB, inorganic carbon is first incorporated by bacteria, then transferred to the rest of the tissues including the digestive system and vital organs, muscle and mantle tissues being the last ones to get this carbon. Carbon transfer from the gills to symbiontfree tissue was observed earlier in the MOB-housing seep Bathymodiolus sp. by Fisher and Childress (1992) who detected an increase of radiolabel coming from ${ }^{14} \mathrm{CH}_{4}$ in symbiont-free tissues during a chase period. Evidence for intracellular digestion of symbionts in the same mussel species was provided later by Streams et al. (1997). Partially degraded bacteria in bacteriocyte bodies with lysosomal activity were also observed in B. azoricus (Fiala-Médioni et al., 2002), indicating that this could be the mode of carbon transfer from the symbiont to the host. The slow transfer of ${ }^{13} \mathrm{C}$ from either $\mathrm{CH}_{4}$ or $\mathrm{HCO}_{3}^{-}$(in the presence of $\mathrm{H}_{2} \mathrm{~S}$ ) to the muscle tissue relative to the gill (Fig. 5) may reflect differences in tissue turnover: gill tissue hosts the bacteria that continuously incorporate the tracer, and hence show a ${ }^{13} \mathrm{C}$ abundance more like that of the symbionts; muscle tissue, in contrast, contains exclusively $\mathrm{C}$ accumulated through the entire life of the mussel, and its ${ }^{13} \mathrm{C}$ abundance, therefore, is less responsive to recently ingested food. Our calculations based on the results of May tracer experiments thus indicate 3 and 5-10 times slower carbon incorporation rates in muscle tissue than in symbiont-containing gill tissue for SOB and MOB, respectively (Fig. 5).

We finally measured a median incorporation rate of $0.28 \pm 0.06 \mu \mathrm{mol} \mathrm{Cg}^{-1}$ dry gill $\mathrm{h}^{-1}$ in adult B. azoricus ( $n=13$, mussels collected after 4 and 20 days, median shell length $=65.8 \pm 4.7 \mathrm{~mm}$ ) with enriched bicarbonate in the presence of sulphide at concentrations close to the ones measured over mussel beds at Menez Gwen and Lucky Strike vents (Table 2). In contrast, mussels kept for up to 15 days with $28 \mu \mathrm{mol} \mathrm{L}^{-1}$ enriched $\mathrm{CH}_{4}$ (median concentration) displayed slow carbon incorporation rates $\left(0.07 \pm 0.07 \mu \mathrm{mol} \mathrm{Cg}^{-1}\right.$ dry gill $\mathrm{h}^{-1}, n=10$, shell length $=62.2 \pm 1.8 \mathrm{~mm}$, medians $\pm \mathrm{SD}$ ). The high standard deviations in carbon incorporation rates measured for both ex- periments could be the result of differential valve opening behaviour or of differences in initial symbiont abundances between specimens following the maintenance period. Mussels maintained in LabHorta for 38 days before labelling showed a quick drop in symbiont abundance compared to wild mussels, which could explain part of the very low carbon incorporation from enriched methane. Kochevar et al. (1992) described in more details the characteristics inherent to MOB from a seep Bathymodiolid in a study using ${ }^{14} \mathrm{CH}_{4}$. They showed that about $70 \%$ of the consumed methane was incorporated as organic compounds. The highest net carbon incorporation rate $\left(5 \mu\right.$ moles $\mathrm{Cg}^{-1}$ wet mussel $\left.\mathrm{h}^{-1}\right)$ was obtained at $250 \mu \mathrm{mol} \mathrm{L}^{-1}$ dissolved methane. Our rate estimates cannot really be compared to the rates obtained by Kochevar et al. (1992), as they are reported per dry gill weight as opposed to wet whole mussel soft tissue weight, plus our experiments were performed with a 9 times lower median methane concentration with mussels maintained in aquarium. However, we provide the first experimental data on carbon fixation in "acclimated" Bathymodiolus azoricus.

Although working at atmospheric pressure, the LabHorta aquarium setting can thus be employed to study the dynamics of symbiont populations. In the future, pulses of varying intensities and durations or parallel measurements of rates of symbiont digestion by the host should be foreseen. Together with the identification of biomarkers for the endosymbionts following tracer experiments, such experiments should provide useful tools to study the effects of changes in hydrothermal fluids on the chemosynthetic nutrition of the Mid-Atlantic Ridge mussel and gain insight in the extent to which the mussel beds interact with and impact their surroundings.

Acknowledgements. We thank C. Leal, V. Costa, M. Korntheuer, M. Laranjo, H. Lopez and L. Pires for the experimental support, and P. Dando and P. Bodelier for helpful advice. Our acknowledgements also go to the Victor 6000 team, crews of "R/V Arquipélago" and "Pourquoi Pas?" and chief scientists of the MoMARETO cruise J. Sarrazin and P. M. Sarradin. Financial support for this research was provided by the EU Framework Contract No EVK3-CT1999-00003 (VENTOX, cage system), the Azorean DRCT (Portugal) and the Portuguese FCT (LabHorta and IMAR-DOP/UAç Research Unit \#531 and Associate Laboratory \#9 lab work and SFRH/BPD/35808/2007, grant RB), and by the EU research training network MoMARnet-FP6-RTN/2003/505026 (grant VR), the EU network of excellence REX-3DEM (CT 502828, grant SH) and FWO-Vlaanderen (G.0632.06) and PRODESA/Feder. We are finally grateful to the reviewers, who considerably helped improving this manuscript. This is publication 4438 of the Netherlands Institute of Ecology (NIOO-KNAW).

Edited by: A. Boetius 


\section{References}

Abramoff, M. D., Magelhaes, P. J., and Ram, S. J. : Image processing with ImageJ, Biophotonics Int., 11, 36-42, 2004.

Arndt, C., Gaill, F., and Felbeck, H.: Anaerobic sulfur metabolism in thiotrophic symbioses, J. Exp. Biol., 204, 741-750. 2001.

Baxter, J., Hirt, R., Bodrossy, L., Kovacs, K., Embley, T., Prosser, J., and Murrell, J.: The ribulose-1,5-bisphosphate carboxylase/oxygenase gene cluster of Methylococcus capsulatus (Bath), Arch. Microbiol., 177, 279-289, 2002.

Belkin, S., Nelson, D. C., and Jannasch, H. W.: Symbiotic assimilation of $\mathrm{CO}_{2}$ in two hydrothermal vent animals, the mussel Bathymodiolus thermophilus and the tube worm Riftia pachyptila, Biol. Bull., 170, 110-121, 1986.

Bettencourt, R., Roch, P., Stefanni, S., Rosa, D., Colaço, A., and Santos, R. S.: Deep sea immunity: unveiling immune constituents from the hydrothermal vent mussel Bathymodiolus azoricus, Mar. Environ. Res., 64(2), 108-127, 2007.

Bettencourt, R., Dando, P., Rosa, D., Riou, V., Colaço, A., Sarrazin, J., Sarradin, P. M., and Santos, R. S.: Changes of gill and hemocyte- related bio-indicators during long term maintenance of the vent mussel Bathymodiolus azoricus held in aquaria at atmospheric pressure, Comp. Biochem. Physiol., Part A, 150(1), $1-7,2008$.

Cavanaugh, C. M., Levering, P. R., Maki, J. S., Mitchell, R., and Lidstrom, M. E.: Symbiosis of methylotrophic bacteria and deepsea mussels, Nature, 325, 346-347, 1987.

Cavanaugh, C. M., Wirsen, C. O., and Jannasch, H. W.: Evidence for methanotrophic symbionts in a hydrothermal vent mussel (Bivalvia: Mytilidae) from the Mid-Atlantic Ridge, Appl. Environ. Microb., 58, 3799-3803, 1992.

Childress, J. J., Fisher, C. R., Brooks, J. M., Kennicutt, M. C., Bidigare, R., and Andreson, A. E. : A methanotrophic marine molluscan (Bivalvia, Mytilidae) symbiosis: mussels fueled by gas, Science, 233(4770), 1306-1308, 1986.

Colaço, A., Dehairs, F., Desbruyères, D., Le Bris, N., and Sarradin, $\mathrm{P}$. M.: $\delta^{13} \mathrm{C}$ signature of hydrothermal mussels is related with the end-member fluid concentration of $\mathrm{H}_{2} \mathrm{~S}$ and $\mathrm{CH}_{4}$ at the Mid-Atlantic Ridge hydrothermal vent fields, Cah. Biol. Mar., 43, 259-262, 2002a.

Colaço, A. and Santos, R. S.: LABHORTA, A Land-based laboratory for vent studies, in Towards Planning of Sea-floor Observatory Programs for the MAR region (Proceedings of the II MoMAR Workshop), Arquipélago, Life and Marine Sciences, Supplement 3, XII, edited by: Santos, R. S., Escartin, J., Colaço, A., and Adamczewska, A., 36, 2002 b.

Company, R., Serafim, A., Cosson, R. P., Fiala-Médioni, A., Camus, L., Colaço, A., Santos, R. S., and Bebianno, M. J.: Antioxidant biochemical responses to long-term copper exposure in Bathymodiolus azoricus from Menez-Gwen hydrothermal vent, Sci. Total Environ., 389(2-3), 407-417, 2008.

Desbruyères, D., Almeida, A., Biscoito, M., Comtet, T., Khripounoff, A., Le Bris, N., Sarradin, P. M., and Segonzac, M.: A review of the distribution of hydrothermal vent communities along the northern Mid-Atlantic Ridge: dispersal vs. environmental controls, Hydrobiologia, 440, 201-216, 2000.

de Zwaan, A., de Bont, A. M. T., and Hemelraad, J.: The role of phosphoenolpyruvate carboxykinase in the anaerobic metabolism of the sea mussel Mytilus edulis, J. Comp. Physiol., 153B, 267-274, 1983.
Dixon, D. R., Pruski A. M., and Dixon, L. R. J.: The effects of hydrostatic pressure change on DNA integrity in the hydrothermalvent mussel Bathymodiolus azoricus: implications for future deep-sea mutagenicity studies, Mutat. Res., 552, 235-246, 2004.

Duperron, S., Nadalig, T., Caprais, J. C., Sibuet, M., Fiala-Médioni, A., Amann, R., and Dubilier, N.: Dual symbiosis in a Bathymodiolus sp. mussel from a methane seep on the Gabon continental margin (Southeast Atlantic): 16S rRNA phylogeny and distribution of the symbionts in gills, Appl. Environ. Microb., 71(4), 1694-1700, 2005.

Duperron, S., Bergin, C., Zielinski, F., Blazejak, A., Pernthaler, A., McKiness, Z. P., DeChaine, E., Cavanaugh, C. M., and Dubilier, N.: A dual symbiosis shared by two mussel species, Bathymodiolus azoricus and Bathymodiolus puteoserpentis (Bivalvia: Mytilidae), from hydrothermal vents along the northern Mid-Atlantic Ridge, Environ. Microbiol., 8, 1441-1447, 2006.

Duperron, S., Sibuet, M., MacGregor, B. J., Kuypers, M. M. M., Fisher, C. R., and Dubilier, N.: Diversity, relative abundance and metabolic potential of bacterial endosymbionts in three Bathymodiolus mussel species from cold seeps in the Gulf of Mexico, Environ. Microbiol., 9, 1423-1438, 2007.

Duperron, S., Laurent, M. C. Z., Gaill, F., and Gros, O.: Sulphuroxidizing extracellular bacteria in the gills of Mytilidae associated with wood falls, FEMS Microbiol. Ecol., 63(3), 338-349, 2008.

Elsaied, H. E., Kaneko, R., and Naganuma, T.: Molecular characterization of a deep-sea methanotrophic mussel symbiont that carries a RuBisCO Gene, Mar. Biotechnol., 8, 511-520, 2006.

Fiala-Médioni, A., Alayse, A. M., and Cahet, G.: Evidence of in situ uptake and incorporation of bicarbonate and amino acids by a hydrothermal vent mussel, J. Exp. Mar. Biol. Ecol., 96, 191198, 1986.

Fiala-Médioni, A., McKiness, Z. P., Dando, P., Boulegue, J., Mariotti, A., Alayse-Danet, A. M., Robinson, J. J., and Cavanaugh, C. M.: Ultrastructural, biochemical, and immunological characterization of two populations of the mytilid mussel Bathymodiolus azoricus from the Mid-Atlantic Ridge: evidence for a dual symbiosis, Mar. Biol., 141, 1035-1043, 2002.

Fisher, C. R.: Chemoautotropic and methanotrophic symbioses in marine invertebrates, Crit. Rev. Aquat. Sci., 2, 399-436, 1990.

Fisher, C. R. and Childress, J. J.: Organic carbon transfer from methanotrophic symbionts to the host hydrocarbon-seep mussel, Symbiosis, 12, 221-235, 1992.

Fisher, C. R., Brooks, J. M., Vodenichar, J. S., Zande, J. M., Childress, J. J., and Burke Jr., R. A. : The co-occurrence of methanotrophic and chemoautotrophic sulfur oxidizing bacterial symbionts in a deep-sea mussel, Mar. Ecol., 14, 277-289, 1993.

Glover, H. E.: Measurement of chemoautotrophic $\mathrm{CO}_{2}$ assimilation in marine nitrifying bacteria: an enzymatic approach, Mar. Biol., 74, 295-300, 1983.

Grieshaber, M. K., Hardewig I., Kreutzer, U., and Pörtner, H. O.: Physiological and metabolical responses to hypoxia in invertebrates, Rev. Physiol. Bioch. P., 125, 43-147, 1994.

Halary, S., Riou, V., Gaill, F., Boudier, T., and Duperron, S.: 3D FISH for the quantification of methane- and sulphur-oxidizing endosymbionts in bacteriocytes of the hydrothermal vent mussel Bathymodiolus azoricus, ISME J., 2(3), 284-292, 2008.

Kadar, E., Bettencourt, R., Costa, V., Santos, R. S., Lobo-da-Cunha, A., and Dando, P.: Experimentally induced endosymbiont loss 
and re-acquirement in the hydrothermal vent bivalve Bathymodiolus azoricus, J. Exp. Mar. Biol. Ecol., 318, 99-110, 2005.

Kates, M.: Bacterial lipids, Adv. Lipid Res., 2, 17-90, 1964.

Knief, C., Altendorf, K., and Lipski, A.: Linking autotrophic activity in environmental samples with specific bacterial taxa by detection of ${ }^{13} \mathrm{C}$-labelled fatty acids, Environ. Microbiol., 5(11), 1155-1167, 2003a.

Knief, C., Lipski, A., and Dunfield, P. F.: Diversity and activity of methanotrophic bacteria in different upland soils, Appl. Environ. Microb., 69(11), 6703-6714, 2003b.

Kochevar, R. E., Childress, J. J., Fisher, C. R., and Minnich, E.: The methane mussel: Roles of symbiont and host in the metabolic utilization of methane, Mar. Biol., 112, 389-401, 1992.

Lee, R. W. and Childress, J. J.: Assimilation of inorganic nitrogen by seep mytilid Ia, an undescribed deep-sea mussel containing methanotrophic endosymbionts: Fate of assimilated nitrogen and the relation between methane and nitrogen assimilation, Mar. Ecol. Prog. Ser., 123, 137-148, 1995.

Müller-Kraft, G., Uhlenhut, J., and Babel, W.: Heterotrophic carbon dioxide fixation by a methylotrophic Ancylobacter species, J. Basic Microb., 31 (4), 317-319, 1991.

Nelson, D. C., Hagen, K. D., and Edwards, D. B.: The gill symbiont of the hydrothermal vent mussel Bathymodiolus thermophilus is a psychrophilic, chemoautotrophic, sulfur bacterium, Mar. Biol., 121, 487-495, 1995.

Pearson, A., Brocks, J. J., and Budin, M.: Phylogenetic and biochemical evidence for sterol biosynthesis in the bacterium Gemmata obscuriglobus, P. Natl. Acad. Sci. USA, 100(26), 15352$15357,2003$.

Pruski, A. M., Rousse, N., Fiala-Médioni, A., and Boulègue, J.: Sulphur signature in the hydrothermal vent mussel Bathymodiolus azoricus from the mid-Atlantic Ridge, J. Mar. Biol. Assoc. UK, 82(3), 463-468, 2002.

Robinson, J. J., Polz, M. F., Fiala-Médioni, A., and Cavanaugh, C. M.: Physiological and immunological evidence for two distinct pathways in Bathymodiolus puteoserpentis (Bivalvia: Mytilidae), a dual endosymbiotic mussel from the Mid-Atlantic Ridge, Mar. Biol., 132, 625-633, 1998.
Salerno, J., Macko, S. A., Hallam, S. J., Bright, M., Won, Y.J., McKiness, Z., and Van Dover, C. L.: Characterization of Symbiont Populations in Life-History Stages of Mussels From Chemosynthetic Environments, Biol. Bull., 208, 145-155, 2005.

Sarradin, P. M., Caprais, J. C., Riso, R., Comtet, T., and Aminot, A.: Brief account of the chemical environment at hydrothermal vent mussel beds on the MAR, Cah. Biol. Mar., 39, 253-254, 1998.

Sibuet, M. and Olu, K.: Biogeography, biodiversity and fluid dependence of deep sea cold seep communities at active and passive margins, Deep-Sea Res. Part II, 45, 517-567, 1998.

Schobert, P. and Bowien, B.: Unusual C3 and C4 metabolism in the chemoautotroph Alcaligenes eutrophus, J. Bacteriol., 159(1), 167-172, 1984.

Smith, K. L. J.: Deep-sea hydrothermal vent mussels: nutritional state and distribution at the Galapagos rift, Ecology, 66, 10671080, 1985.

Streams, M. E., Fisher, C. R., and Fiala-Médioni, A.: Methanotrophic symbiont location and fate of carbon incorporated from methane in a hydrocarbon seep mussel, Mar. Biol., 129(3), 465476, 1997.

Trask, J. L. and Van Dover, C. L.: Site-specific and ontogenetic variations in nutrition of mussels (Bathymodiolus sp.) from the Lucky Strike hydrothermal vent field, Mid-Atlantic Ridge, Limnol. Oceanogr., 44, 334-343, 1999.

Van Dover, C. L.: The ecology of deep-sea hydrothermal vents, Princeton University Press, Princeton, N. J., 192-194, 2000.

White, D. C., Davis, W. M., Nickels, J. S., King, J. D., and Bobbie, R. J.: Determination of the sedimentary microbial biomass by extractable lipid phosphate, Oecologia, 40, 51-62, 1979.

Won, Y. J., Hallam, S. J., O’Mullan, G. D., Pan, I. L., Buck, K. R., and Vrijenhoek, R. C.: Environmental Acquisition of Thiotrophic Endosymbionts by Deep-Sea Mussels of the Genus Bathymodiolus, Appl. Environ. Microb., 69(11), 6785-6792, 2003. 